JEBIS: Jurnal Ekonomi dan Bisnis Islam

Vol. 5, No.2, Juli - Desember 2019

p-ISSN : 2442-6563 e-ISSN : 2525-3027

Page $168-180$

\title{
THE EFFECT OF BEAUTY INFLUENCER, LIFESTYLE, BRAND IMAGE AND HALAL LABELIZATION TOWARDS HALAL COSMETICAL PURCHASING DECISIONS
}

\author{
Alfitri Zukhrufani \\ Muamalat (Ekonomi dan Perbankan Islam), Fakultas Agama Islam, Universitas \\ Muhammadiyah Yogyakarta \\ Email: zk_fani@yahoo.com \\ Muhammad zakiy \\ Muamalat (Ekonomi dan Perbankan Islam), Fakultas Agama Islam, Universitas \\ Muhammadiyah Yogyakarta \\ Email:muhammad.zakiy@fai.umy.ac.id
}

ARTICLE HISTORY

Received:

2019-08-02

Accepted:

2019-12-03

Online available:

2019-12-31

Keywords:

Beauty

influencers,

lifestyle, brand

image, halal

labelling,

purchasing

decisions

Kata Kunci:

Beauty influencer, gaya hidup, brand image, labelisasi halal, keputusan pembelian
ABSTRACT

This study aims to determine the effect of beauty influencers, lifestyle, brand image and halal labelling on purchasing decisions for halal cosmetics. In this study using a quantitative method with cross sectional analysis. The variable measurement scale is done using a likert scale. The sample in this study was a student of Muhammadiyah Yogyakarta University who used halal cosmetics and had read or watched videos about cosmetics from a Beauty Influencer. The number of samples collected and successfully analyzed as many as 226 of the 242 respondents taken by using purposive sampling technique. The object of analysis in this study is halal cosmetic products. The analytical method used is multiple regression analysis. The results of this study show that the beauty influencer, lifestyle, brand image and labelling halal have a positive effect on purchasing decisions of halal cosmetics.

\section{ABSTRAK}

Penelitian ini bertujuan untuk mengetahui pengaruh beauty influencer, gaya hidup, brand image dan labelisasi halal terhadap keputusan pembelian kosmetik halal. Dalam penelitian ini menggunakan metode kuantitatif dengan studi cross sectional. Skala pengukuran variabel dilakukan dengan menggunakan skala likert. Sampel dalam penenlitian ini adalah Mahasiswi Universitas Muhammadiyah Yogyakarta yang menggunakan kosmetik halal dan pernah membaca atau 
menonton video tentang kosmetik dari seorang Beauty Influencer. Jumlah sampel yang terkumpul dan berhasil dianalisis sebanyak 226 dari 242 responden yang diambil dengan metode purposive sampling. Objek analisis dalam penelitian ini yaitu produk kosmetik halal. Metode analisis yang digunakan adalah analisis regresi berganda. Hasil penenlitian ini menunjukan bahwa beauty influencer,gaya hidup ,brand image dan labelisasi halal berpengaruh positif terhadap keputusan pembelian kosmetik halal.

\section{PENDAHULUAN}

Perkembangan teknologi dan informasi sangat mempengaruhi perilaku konsumen yang ingin serba praktis dan efisien baik dalam konsumsi produk untuk memenuhi kebutuhan maupun keinginan mereka. Saat ini media sosial menjadi sebuah kebutuhan sehari-hari seseorang, tentunya dapat berpengaruh pada cara berkomunikasi perusahaan dengan konsumennya. Hal ini mendorong perusahaan untuk pandai membaca situasi pasar dimasyarakat untuk berbagi informasi secara terbuka.

Penelitian studi literature yang dilakukan (Tri, 2018) tentang pengaruh influencer marketing sebagai strategi pemasaran digital era moderen menyimpulkan bahwa influencer marketing merupakan salah satu strategi pemasaran dengan memanfaatkan platform media sosial. Selain itu peran influencer marketing cocok digunakan untuk meningkatkan citra merek (Brandi Image) secara efektif dan meningkatkan Brand Awareness konsumen terhadap merek tersebut. Menurut Arif (2019) Influencer memiliki topik yang jelas dan terfokus.

Beauty Influencer merupakan salah satu bentuk strategi pemasaran digital dengan menggunakan strategi influencer marketing. Beauty influencer berfokus pada produk kecantikan seperti kosmetik. Seorang beauty influencer tentu memiliki peran untuk mempromosikan sebuah produk kecantikan dalam bentuk konten video maupun tulisan yang kemudian diunggah pada platform media sosial miliknya, beauty influencer memanfaatkan media sosialnya karena jumlah pengikut mereka yang cukup banyak dan mereka memiliki pengaruh yang kuat terhadap pengikut mereka. Ananda dan Wandebori (2016) menjelaskan bahwa kreator pada platform media sosial menjadi sosok aspirasional yang memiliki pengaruh kuat di benak konsumen. Hal ini tentu dapat mendorong produk kecantikan melirik peluang beauty influencer berpotensi sebagai salah satu media promosi yang cukup ampuh. Menurut Sinaga dkk (2018) ulasan mengenai produk yang diberikan oleh seorang beauty influencer secara tidak langsung akan merangsang niat beli penonton. Sehingga beauty influencer berpengaruh terhadap naiknya eksistensi dan penjualan brand tersebut.

Gaya hidup merupakan salah satu hal yang mudah terpengaruh. Gaya hidup seseorang dapat terpengaruh ketika mereka memiliki kecenderungan minat atau 

2019

passion yang sama termasuk dalam memutuskan melakukan pemembelian suatu produk untuk menunjang kebutuhan hidupannya baik penampilan maupun sosial. Menurut Miron dan Mowen (2000), gaya hidup menunjukan bagaimana seseorang hidup, bagaimana dia membelanjakan uangnya, dan bagaimana mengalokasikan waktu. Gaya hidup juga menggambarkan keseluruhan pribadi yang berinteraksi dengan lingkungan. Riset yang dilakukan oleh He dkk (2010) tentang pengaruh gaya hidup terhadap konsumsi kosmetik, dimana gaya hidup memiliki sebuah konsep yang dapat menggambarkan kebutuhan dan keinginan. Hasil riset menunjukan bahwa konsumen memutuskan untuk membeli sebuah produk sesuai dengan gaya hidup sekarang maupun yang akan datang. Banyak penelitian membuktikan pengaruh gaya hidup terhadap keputusan pembelian (Saragih, 2013; Fadhilah, 2018)

Brand image tidak luput dari munculnya persepsi masyarakat terhadap sebuah produk. Menurut Simamora (2003) sebuah merek memiliki image untuk memudahkan konsumen ingat terhadap sebuah merek. Dengan membuat brand image yang tepat, maka akan mempengaruhi penilaian konsumen tidak hanya untuk memenuhi kebutuhanya melainkan dapat memberikan kepuasan yang maksimal. Schiffman dan Kanuk (2007) berpendapat bahwa konsumen senantiasa memilih merek berdasarkan citranya.

Seiring dengan tren kaum Muslim yang sadar akan produk yang aman membuat seseorang mencari tahu mengenai produk-produk halal yang dapat digunakan salah satunya produk kosmetik. Salah satu hal yang sangat mendasar bagi umat Islam untuk menjamin keamanan produk yaitu dengan adanya label halal pada produk kemasan. Di Indonesia volume brand kosmetik yang mengusung konsep halal semakin meningkat. Ketika konsumen mengetahui suatu produk memiliki label halal tentu akan berfikir jika produk tersebut sudah terjamin kemanannya. Semakin baik brand image yang ada di benak konsumen akan semakin meningkat keputusan pembelian (Gumelar, 2016). Sehingga sangat penting pengaruhnya atas keputusan seseorang untuk membeli sebuah produk. A.B Susasnto \& Himawan (2004) menjelaskan mengenai sebuah merek memiliki kekuatan yang dapat menarik konsumen untuk menggunakannya sebagai faktor penentu dalam pemelihan keputusan pembelian.

Saat ini komsetik menjadi sebuah kebutuhan utama bagi wanita untuk menunjang penampilan sehingga penting untuk memperhatikan kosmetik yang aman ketika di gunakan. Produk kosmetik memiliki resiko dalam pemakaian yang perlu diperhatikan mengingat kandungan bahan-bahan kimia tidak selalu memberi efek yang sama untuk setiap konsumen (Ferrinadewi, 2005). Kosmetik yang tidak halal dapat terindikasi bahwa terdapat kandungan dan dalam proses pembuatannya tidak sesuai dengan syariat Islam. Menurut Sandi, dkk (2011) keterangan tentang halal pada produk yang dijual terutama di Indonesia mempunyai arti yang sangat penting dan dimaksudkan untuk melindungi konsumen yang beragama Islam agar terhindar produk yang haram.

Adanya label halal pada kemasan produk, tentu akan mempermudah konsumen dalam mengidentifikasi produk. Menurut Kotler (2009) keputusan pembelian dapat dipengaruhi oleh keyakinan dan sikap. Label halal di Indonesia 
berada di bawah pengawasan Majelis Ulama Indonesia (MUI), Di Indonesia penggunaan label halal mudah ditemukan dan dikenali, seperti contohnya pada produk kosmetik. Tetapi sering kali terjadi penyalahgunaan label halal yang hanya "ditempel" tulisan halal (dengan tulisan arab) pada sebuah produk yang tidak jelas cara pengolahannya dan bahan bakunya. Konsumen yang kurang mengetahui mengenai label halal pada suatu kemasan proaduk akan beranggapan jika label halal yang tercantum pada produk yang dibelinya merupakan label yang sah.

\section{LANDASAN TEORI}

Teori perilaku konsumen menurut Kotler dan Keller (2009) yaitu pengkajian terhadap perseorangan, kelompok, dan organisasi dalam menentukan pilihan, pembelian, penggunaan, dan bagaimana barang, jasa, pemikiran atau pengalaman sebagai alat untuk memuaskan kebutuhan dan keinginan mereka. Mengacu pada teori tersebut maka, seorang konsumen akan menunjukan sikapnya terhadap sebuah pilihan seperti keputusan untuk melakukan pembelian baik berupa barang atau jasa yang dipilihnya, guna memenuhi rasa keinginan untuk memiliki sebagai kebutuhan ataupun cara untuk memuaskan diri.

\section{Pengembangan hipotesis}

\section{Beauty Influencer sebagai pengaruh keputusan pembelian}

Menurut Kotler dan Keller (2009) salah satu peranan dalam perilaku pengambilan keputusan pembelian adalah influencer. Influencer memiliki topik yang jelas dan terfokus, apakah mengenai traveling, beauty, food atau film. Apapun pembahasan yang diangkat harus jelas dan terfokus sehingga mendapatkan relevansi dengan orang-orang yang akan menjadi target market (Arif, 2019). Beauty Influencer merupakan bentuk strategi influencer markrting yang berfokus pada produk kecantikan seperti kosmetik. Beauty influencer merupakan sosok yang memiliki keahlian atau konsentrasi dalam bidang kecantikan yang memberikan informasi terkait produk-produk yang telah mereka gunakan, dan akan memberikan pengalaman dalam menggunakan produk kecantikan (Hutapea, 2016). Beauty influencer bersifat objektif terhadap beragam produk yang mereka gunakan sehingga informasi yang disampaikan pun dapat berupa positif maupun negatif dari produk yang telah digunakan (Sinaga dkk, 2018).

Keputusan pembelian sudah banyak dihubungkan dengan bermacam-macam faktor yang memiliki pengaruh positif seperti harga (Tarigan, 2016), kualitas produk (Silsilia dkk, 2015), celebrity endorser (Gumelar, 2016) dan berpengaruh negatif pada salah satu dimensi beauty influecer yaitu variabel expertise (Rachmah, 2018). Jika diperhatikan dengan baik ketika seorang beauty influencer berbagi informasi dan memiliki keahlian dalam mengajarkan keterampilan tertentu tentang kecantikan dengan menggunkan produk-produk kosmetik yang mereka gunakan, akan timbul daya tarik dan tumbuh kepercayaan yang dapat mempengaruhi pengikutnya untuk 

2019

mencoba, sehingga akan tercipta sebuah keputusan pembelian. Oleh karena itu beauty influencer memiliki pengaruh terhadap naiknya eksistensi maupun penggunaan dan penjualan brand. Atas dasar beberapa penelitian yang ada, menjadikan alasan peneliti untuk membuktikan dengan membangun hipotesis sebagai berikut:

Hipotesis 1: Beauty Influencer berpengaruh terhadap keputusan pembelian kosmetik halal.

\section{Gaya hidup sebagai pengaruh keputusan pembelian}

Salah satu faktor pribadi yang mempengaruhi perilaku konsumen yaitu gaya hidup yang merupakan pola hidup seseorang di dunia yang diekspresikan dalam aktivitas, minat, dan opininya Kolter dan Keller (2009). Gaya hidup sering dijadikan sebagai motivasi dasar dan pedoman dalam keputusan pembelian. Berarti seseorang akan melakukan pembelian mengacu pada gaya hidup yang dianutnya, hal ini sesuai dengan pendapat Hawkins dalam (Yuniarti, 2015) yang menyatakan bahwa gaya hidup seseorang mempengaruhi kebutuhan, keinginan, serta perilakunya termasuk perilaku membeli.

Gaya hidup seseorang dapat berubah seiring dengan perkembangan zaman, hal ini dapat dipengaruhi oleh sebuah keinginan seseorang dalam merubah gaya hidupnya baik itu dalam segi cara berpakaian, kebiasaan maupun tingkah laku. Selain itu gaya hidup juga dapat menggambarkan pola pikir seseorang dalam beraktifitas. Pola pikir dapat mempengaruhi seseorang dalam mengambil keputusan menentukan sebuah pilihan seperti misalnya memutuskan untuk membeli sebuah produk yang menarik baginya. Berdasarkan uraian yang telah dijelaskan, maka peneliti merumuskan hipotesis kedua sebagai berikut:

Hipotesis 2: Gaya Hidup berpengaruh terhadap keputusan pembelian kosmetik halal. Brand image sebagai pengaruh keputusan pembelian

Brand Image memiliki keterkaitan yang erat dengan persepsi terhadap sebuah produk. Menurut Henslowe (Silsilia, 2015) brand image merupakan kesan yang diperoleh menurut tingkatan melalui pengetahuan dan pengertian terhadap fakta mengenai orang, produk, maupun situasi. Dengan menciptakan brand image yang tepat, maka dapat mempengaruhi penilaian konsumen tidak hanya untuk memenuhi kebutuhannya, tetapi dapat memberikan kepuasan yang maksimal.

Adapun hubungan brand image dengan sikap yang menunjukan keyakinan dan preferensi terhadap sebuah brand. Brand image merupakan apa yang dipikirkan konsumen dan dirasakan ketika melihat dan mendengar sebuah brand, konsumen yang positif terhadap suatu brand lebih memungkinkan konsumen untuk memutuskan melakukan pembelian. Schiffman dan Kanuk (2007) berpendapat bahwa konsumen selalu memilih merek berdasarkan citranya. Brand yang dianggap baik juga menjadi dasar untuk membangun image perusahaan yang postif. Berdasarkan uraian yang telah dijelaskan, maka hipotesis penelitian ini:

Hipotesis 3: Brand Image berpengaruh terhadap keputusan pembelian kosmetik halal Labelisasi halal sebagai pengaruh keputusan pembelian

Menurut Kotler (2009) keputusan pembelian dapat dipengaruhi oleh keyakinan dan sikap. Salah satu label yang terdapat pada kemasan produk yaitu label halal. Majelis Ulama Indonesia bekerja sama dengan LPPOM-MUI (Lembaga Pengkajian, 
Pangan, Obat-obatan, dan kosmetik Majelis Ulama Indonesia) adalah lembaga yang diberi wewenang oleh Pemerintah dalam proses sertifikasi halal di Indonesia. Tujuan lebel halal yang mendasar yaitu melindungi konsumen terutama konsumen Muslim, artinya dengan adanya label halal para konsumen Muslim tidak ragu dalam mengonsumsi suatu produk yang di butuhkan. Sehingga dapat menciptakan rasa aman dan nyaman dalam mengonsumsi produk tersebut sehingga meningkatkan kepercayaan serta tercipta keputusan pembelian.

Hipotesis 4: Labelisasi halal berpengaruh terhadap keputusan pembelian kosmetik halal.

\section{Berdasarkan uraian penelitian sebelumnya maka kerangka konseptual pembentukan hipotesis dapat dijelaskan pada Gambar 1}

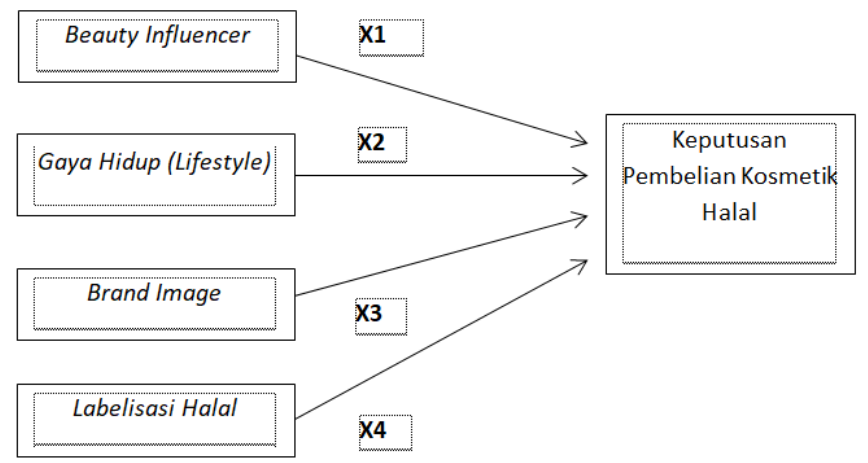

Gambar 1. Kerangka Konseptual Pembentukan Hipotesis

Dari gambar diatas dapat diartikan bahwa teori dan asumsi peneliti yang telah dibangun memiliki keterkaitan antara variabel yang akan diteliti yaitu beauty influencer (X1), gaya hidup (X2), brand image (X3), labelisasi halal (X4) berpengaruh positif terhadap keputusan pembelian kosmetik halal $(\mathrm{Y})$.

\section{METODE PENELITIAN}

Sampel dan Prosedur

Responden dalam penelitian ini adalah Mahasiswi S1 aktif Universitas Muhammadiyah Yogyakarta. Kriteria responden yang dipilih yaitu wanita yang mengguna kosmetik dan pernah membaca atau menonton video tentang kosmetik dari seorang Beauty Influencer. Penyebaran kuesioner penelitian ini menggunakan 2 jenis yakni offline dan menyebarkan link kuesioner secara online. Total tabulasi kuesioner yang terkumpul sebanyak 242 dan kuesioner yang dapat diolah sebanyak 226. Banyaknya kuesioner yang tidak dapat diolah karena responden dalam pengisian kuesioner tidak diisi dengan baik atau tidak serius, sehingga peneliti merasa tidak obyektif jika di input atau dimasukan. Selain itu, terdapat responden yang tidak menggunakan kosmetik halal.

Responden yang telah mengisi kuesioner dengan lengkap tersebar pada 7 fakultas didominasi oleh Fakultas Kedokteran dan IImu Kesehatan (FKIK) sejumlah 47 orang $(20,8 \%)$. Sedangkan jumlah responden terendah sebanyak 11 orang $(4,9 \%)$ pada 

2019

Fakultas Hukum. Sebaran kuesioner pada 19 jurusan yang didominasi oleh jurusan Ekonomi Syariah yaitu sebanyak 19 orang $(8,4 \%)$. Sedangkan jumlah responden terendah pada 3 jurusan dengan masing masing sebanyak 9 orang $(4,0 \%)$ pada jurusan IImu Pemerintahan, PSIK dan Pendidikan Bahasa Jepang. Untuk status usia responden yang berusia 17-20 tahun sejumlah 60 orang $(26,5 \%)$ dan responden yang berusia $21-$ 24 tahun sejumlah 166 orang (73,5\%). Variabel demografi terakhir yaitu uang saku perbulan dengan rentang uang saku perbulan Rp.1.000.000 - Rp.2.000.000 mendominasi yakni sebesar 144 orang $(63,7 \%)$, responden dengan uang saku perbulan < Rp.1.000.000 sejumlah 51 orang (22,6\%) kemudian diikuti dengan 31 orang $(13,7 \%)$ memiliki uang saku Rp. 2.000.000 - Rp. 3.000.000 perbulan.

\section{Pengukuran}

Pengukuran pada penelitian ini menggunakan skala Likert, terdapat besaran skor pada lima tingkatan pilihan jawaban dengan skor " 5 " mewakili sangat setuju dan skor "1" mewakili sangat tidak setuju. Responden diminta untuk menjawab pernyataan-pernyataan yang telah disediakan, meliputi beauty influencer, gaya hidup, brand image, labelisasi halal dan keputusan pembelian.

Beauty influencer, peneliti menggunakan 11 item pernyataan meliputi trustworthiness, expertise, attractiveness indikator ini digunakan pada penelitian yang dilakukan oleh Rachmah (2018). Contoh dari item pernyataan variabel ini adalah "Beauty Influencer memiliki kemampuan meyakinkan penontonnya untuk membeli barang". Nilai Koefisien crombath alpha dalam variabel ini sebesar 0,776.

Gaya hidup, peneliti menggunakan 9 item pernyataan yang dikembangkan oleh Kolter dan Keller (2009). Contoh dari item pernyataan variabel ini adalah "Anda menggunakan produk kosmetik halal dalam keseharian". Nilai Koefisien crombath alpha dalam variabel ini sebesar 0,784.

Brand image, peneliti menggunakan 8 item pernyataan meliputi citra terhadap produk, citra terhadap perusahaan dan citra terhadap pelayanan yang dikembangkan oleh kotler dan Keller (2009). Contoh dari item pernyataan variabel ini adalah "Produk kosmetik halal selalu mengutamakan kualitas". Nilai Koefisien crombath alpha dalam variabel ini sebesar 0,745 .

Labelisasi halal, peneliti menggunakan 8 item pernyataan meliputi gambar, tulisan, kombinasi gambar dan tulisan, menempel pada kemasan indikator ini digunakan pada penelitian yang dilakukan oleh Rafita (2017). Contoh dari item pernyataan variabel ini adalah "Tulisan "Halal" pada gambar terbaca dengan jelas". Nilai Koefisien crombath alpha dalam variabel ini sebesar 0,803.

Keputusan pembelian, peneliti menggunakan 8 item pernyataan yang dikembangkan oleh Kotler dan Keller (2009). Contoh dari item pernyataan variabel ini adalah "Jika Anda membeli kosmetik lagi, Anda akan menetapkan pilihan produk kosmetik halal". Nilai Koefisien crombath alpha dalam variabel ini sebesar 0,744. 


\section{HASIL DAN PEMBAHASAN}

\section{Analisis Faktor}

\section{Model Pengukuran}

Uji kualitas instrumen pada penelitian ini menggunakan softwer SPSS 16 . Uji validitas digunakan untuk mengukur kualitas instrumen. Hal yang dilakukan sebelum menunjukkan bahwa semua indikator layak untuk dijadikan instrumen penelitian, maka perlu dilakukan uji validitas pada butir-butir pernyataan. Suatu indikator di katakan valid jika signifikansi dari setiap item pernyataan adalah $<0,05$. Untuk itu item yang digunakan dalam peneletian ini adalah item pernyataan yang mempunyai nilai signifikansi $<0,05$. Berdasarkan hasil uji validitas pada setiap butir pernyataan menunjukan bahwa semua indikator yang digunakan untuk mengukur variabel beauty influencer, gaya hidup, brand image, labeliasi halal dan keputusan pembelian dalam penelitian ini memiliki nilai signifikan kurang dari $5 \%$ atau dibawah 0,05 . Sehingga semua indikator yang digunakan dalam penelitian ini dinilai layak dan valid untuk digunakan sebagai pengukuran data yang kemudian dapat dianalisis.

Uji Analisis Data

Uji Koefisien Determinasi (Adjusted $R^{2}$ )

Uji koefisien deteminan $\left(R^{2}\right)$ digunakan untuk mengukur seberapa jauh model dalam menerangkan variasi variabel dependen. Berikut hasil pengujian koesfisiensi dalam tabel 1.

Tabel 1

Hasil Uji KoefisienDeterminasi

\begin{tabular}{ccc}
\hline$R$ & $R^{2}$ & Adjusted $R^{2}$ \\
\hline 0,489 & $\mathbf{0 , 2 3 9}$ & $\mathbf{0 , 2 2 5}$ \\
\hline
\end{tabular}

Berdasarkan tabel diatas dapat dilihat bahwa angka Adjusted $R^{2}$ sebesar 0,225, dengan demikian berarti besarnya pengaruh variabel bebas yaitu beauty influencer, gaya hidup, brand image dan labelisasi halal terhadap variabel terikat yaitu keputusan pembelian sebesar $25,5 \%$ dan sisanya sebesar $74,5 \%$ dipengaruhi oleh variabel lain yang tidak ada dalam penelitian ini.

\section{Pengujian hipotesis}

Pada penelitian ini menggunakan metode analisis regresi berganda untuk menguji hipetesis. Hasil pengujian hipotesis dapat dilihat pada tabel 1 sebagai berikut.

Tabel 2

Hasil Uji Hipotesis

\begin{tabular}{ccc}
\hline Keterangan & Koefisien Regresi (B) & Sig \\
\hline Contanta & 7,989 & 0,12 \\
$\begin{array}{c}\text { Beauty Influencer-> } \\
\text { keputusan Pembelian }\end{array}$ & 0,106 & 0,043 \\
$\begin{array}{c}\text { Gaya Hidup-> keputusan } \\
\text { Pembelian }\end{array}$ & 0,131 & 0,009 \\
\end{tabular}


Zukhrufani dan Zakiy |Jurnal Ekonomi dan Bisnis Islam, Vol. 5, No. 2, Juli - Desember 2019
Brand Image->
0,150
0,007
keputusan Pembelian

\begin{tabular}{ccc}
\hline Keterangan & Koefisien Regresi (B) & Sig \\
\hline $\begin{array}{c}\text { Labelisasi Halal-> } \\
\text { keputusan Pembelian }\end{array}$ & 0,316 & 0,000 \\
\hline
\end{tabular}

Hipotesis 1 yang menyatakan Beauty influencer berpengaruh positif terhadap keputusan pembelian. Hasil uji hipotesis menunjukan nilai koefisien sebesar 0,106 dengan nilai signifikansi sebesar 0,043 yang berarti $<0,05$. Hal ini berarti beauty influencer berpengaruh positif terhadap keputusan pembelian didukung. Hasil penelitian ini relevan dengan penelitian yang dilakukan oleh Sinaga dkk (2018).

Hipotesis 2 yang menyatakan Gaya hidup berpengaruh positif terhadap keputusan pembelian. Hasil uji hipotesis kedua memiliki nilai kiefisien sebesar 0,131 dengan nilai signifikansi sebesar 0,009 yang berarti $<0,05$. Hal ini berarti gaya hidup berpengaruh positif terhadap keputusan pembelian didukung. Hasil penelitian ini relavan dengan teori Menurut Hawkins (Yuniarti,2015) dan penelitian sebelumnya yang dilakukan oleh Tarigan (2016).

Hipotesis 3 yang menyatakan brand image berpengaruh positif terhadap keputusan pembelian. Hasil uji hipotesis menunjukan pada variabel ini memiliki nilai koefisien sebesar 0,150 dengan nilai signifikansi sebesar 0,007 yang berarti $<0,05$. Hal ini brand image berpengaruh positif terhadap keputusan pembelian didukung. Hasil penelitian ini relavan dengan penelitian yang dilakukan oleh Sisilia dkk (2015) .

Hipotesis 4 yang menyatakan labelisasi halal berpengaruh positif terhadap keputusan pembelian. Hasil uji hipotesis menunjukan nilai koefisien sebesar 0,316 dengan tingkat signifikansi sebesar 0,000 yang berarti $<0,05$. Hal ini berarti labelisasi halal berpengaruh positif terhadap keputusan pembelian. Pernyataan ini sesuai dengan Kotler dan Kelle (2009) yang menyatakan bahwa keputusan pembelian dapat dipengaruhi oleh keyakinan dan sikap. Selain itu hasil penelitian ini relavan dengan penelitian yang dilakukan oleh Rafita (2017).

Penelitian ini bertujuan untuk menganalisis perilaku konsumen yaitu mahasiswi Universitas Muhamadiyah Yogyakarta dalam melakukan keputusan pembelian produk kosmetik terutama pada produk kosmetik halal. Adapun Faktor-faktor yang diambil memiliki pengaruh dalam sebuah pengambilan keputusan pembelian adalah beauty influencer, gaya hidup, brand image dan labelisasi halal.

Hasil analisis regresi berganda menunjukan pada uji hipotesis pertama. Beauty influencer berpengaruh positif terhadap keputusan pembelian kosmetik halal. Kemampuan beauty influencer dalam meyakinkan penonton dan kejujuran dalam memberikan review sebuah produk kosmetik halal memberikan tingkat kepercayaan terhadap beauty influencer. Keterampilan dan keahlian yang dimiliki beauty influencer dalam memberikan infromasi mengenai sebuah produk yang di review, serta penyampaian dengan menggunakan bahasa yang baik dan memiliki pengalaman dalam menggunakannya, akan memberikan kesan bahwa beauty influencer memiliki keahlian yang berhubungan dengan produk kosmetik. Penampilan yang menarik diikuti dengan 
melalui cara beauty influencer berkomunikasi membuat penonton tertarik, dan semakin baik popularitas yang dimiliki seorang beauty influencer di masyarakat maka akan memberikan daya tarik, sehingga secara langsung mampu mempengaruhi keputusan pembelian.

Hipotesis kedua dalam penelitian ini yang menyatakan bahwa Gaya hidup berpengaruh positif terhadap keputusan pembelian didukung. Menggunkan kosmetik halal menjadi aktifitas dalam keseharian yang disukai, selain menjadikan sebuah kebutuhan penggunaan kosmetik halal yang termasuk dalam barang mewah akan menggambarkan pemiliknya, sehingga produk kosmetik halal lebih dipilih untuk menjaga penampilan. Hasil penelitian ini mendukung teori Menurut Hawkins (Yuniarti,2015) yang menjelaskan bahwa gaya hidup seseorang mempengaruhi kebutuhan, keinginan, serta perilakunya termasuk perilaku membeli.

Hasil pengujian hipotesis yang didukung juga ditunjukan untuk hipotesis ketiga yang menyatakan brand image berpengaruh positif terhadap keputusan pembelian. Hal ini membuktikan bahwa brand image memiliki hubungan yang kuat terhadap keputusan pembelian dengan kesan yang positif terhadap produk akan tercipta image yang baik di benak konsumen. Tercapainya tingkat kepuasan yang berikan oleh perusahaan dan optimalnya layanan yang diberikan maka mendorong terciptanya keputusan pembelian. Semakin baik image suatu produk maka akan semakin meningkat keputusan pembelian.

Hasil hipotesisi ke empat pada variabel labelisasi halal yang menyatakan menyatakan labelisasi halal berpengaruh positif terhadap keputusan pembelian didukung penuh. Adanya label halal pada kemasan produk menjadikan pertimbangan dan memudahkan untuk mengidentifikasi produk sehingga lebih meyakinkan konsumen dalam membeli produk. Label halal yang terdapat pada kemasan akan memberikan rasa aman dan percaya akan kehalalan dan mutu produk. Dari persepsi tersebut proses dimana orang akan memilih dan mempertimbangkan produk yang akan dikonsumsi. Dengan adanya labelisasi halal pada kemasan pada akhirnya akan mempengaruhi keputusan pembelian kosnumen. Pernyataan ini sesuai dengan Kotler dan Kelle (2009) yang menyatakan bahwa keputusan pembelian dapat dipengaruhi oleh keyakinan dan sikap.

Berdasarkan hasil penelitian ini, maka dapat dikatakan bahwa beauty influencer, gaya hidup, brand image dan labelisasi halal menjadi faktor-faktor yang memiliki pengaruh dalam sebuah pengambilan keputusan pembelian kosmetik halal yang dilakukan oleh Mahasiswi Universitas Muhamadiyah Yogyakarta. Selain itu penelitian ini menunjukan perilaku seorang konsumen Muslim dalam memilih produk untuk memenuhi kebutuhannya.

\section{Implikasi Penelitian}

Implikasi Teoritis. Hasil penelitian ini dapat dijadikan bukti empiris yang menjelaskan pengaruh beauty influencer, gaya hidup, brand image dan labelisasi halal terhadap keputusan pembelian kosmetik halal. Selain itu penelitian ini dapat dijadikan acuan 

2019

untuk penelitian selanjutnya dengan tema yang sama yaitu perilaku konsumen terhadap keputusan pembelian.

Implikasi praktis. Hasil dari penelitian ini memberikan kontribusi terhadap perusahaan dengan para pengambilan kebijakan dalam perusahaan terutama mengenai strategi pemasaran yang tepat untuk meningkatkan penjualan dan citra produk sehingga perusahaan yang dapat membaca kondisi pasar dengan baik dan benar tentu akan menarik simpati seorang investor. Seorang investor memerlukan refrensi dalam mempertimbangkan pengambilan keputusan berinvestasi pada sektor industri perdaganga khususnya dalam sektor pedagangan kosmetik. Dengan mengetahui trend suatu perusahaan atau produk dari suatu perusahaan melalui fenomena di masyarakat tentu akan membantu seorang investor untuk berinvestasi di perusahaan tersebut.

\section{SIMPULAN}

Penelitian ini memiliki beberapa kelemahan yang tentunya harus diperbaiki dalam penelitian selanjutnya. Pertama, banyak faktor-faktor yang dapat mempengaruhi konsumen dalam mengambil keputusan pembelian suatu produk. Namun peneliti hanya mengambil faktor beauty influencer, gaya hidup (life style), dan labelisasi halal. Hal ini dipilih karena terdapat variabel yang belum banyak diteliti khususnya pada produk kosmetik. Sehingga untuk penelitian selanjutnya diharapkan menambah variabel diluar variabel yang telah diteliti, misalnya persepsi harga religiustisitas dan influencer marketing dan lain-lain agar diperoleh hasil yang lebih bervariatif yang dapat mempengaruhi keputusan pembelian khususnya pada produk kosmetik halal. Kedua Objek dalam penelitian ini hanya dilakukan pada tingkat mahasiswi yaitu pada Mahasiswi Universitas Muhammadiyah Yogyakarta. Untuk penelitian selanjutnya disarankan agar dapat memperluas objek penelitian sehingga dapat memperluas ruang lingkup penelitian atau mengambil objek dari berbagai segmen lain.

\section{DAFTAR PUSTAKA}

Ananda, A \& Wandebori, H. 2016. "The impact of drugstore makeup product reviews by beauty vlogger on youtube towards purchase intention undergraduate students in Indonesia International Conference on Ethics of Business, Economics, and Social Science, 264-273

Fadhilah, Fauz Novia. 2018. Pengaruh Gaya Hidup Konsumtif Dan Beauty Vlogger Sebagai Kelompok Referensi Terhadap Keputusan Pembelian Kosmetik Studi Kasus Pada Remaja Perempuan Pengguna Kosmetik Korea Di Surabaya. Jurnal IImu Manajemen. Vol. 7, No. 1: 133-142

Ferrinadewi, Erna. 2005. Atribut Produk yang Dipertimbangkan dalam Pembelian Kosmetik dan Pengaruhnya pada Kepuasan Konsumen di Surabaya. Jurnal Manajemen dan Kewirausahaan, Vol.7 No.2 September.

Gumelar, Brian. 2016. Pengaruh Brand Image Dan Celebrity Endorser Terhadap Keputusan Pembelian Kosmetik Wardah. Skripsi. Program Studi Manajemen. Universitas Negeri Yogyakarta. 
He, Yanqun, Deqiang Zou \& Liyin Jin. (2010). Exploiting the goldmine: a lifestyle analysis of affluent Chinese Consumers. Jurnal of Consumer Marketing. Vol.27

Hutapea. 2016. Pengaruh Beauty Vlogger Dan Brand Image Survei Pengaruh Beauty Vlogger Sebagai Endorser Terhadap Brand Image Produk The Body Shop. Skripsi. Departemen Ilmu Komunikasi. Universitas Gajah Mada

John C. Mowen, \& Michael Minor. 2002. Perilaku Konsumen. Jilid II Edis Bahsa Indonesia. Jakarta: Penerbit Erlangga

Kotler, Philip \& Kevin Lane Keller. 2009. Manajemen Pemasaran. Edisi13 jilid 1. Erlangga: Jakarta

L.G. Schiffman dan L.L. Kanuk. 2007. Consumers Behaviour. New Jersey: Pearson Prentice Hall

Rachmah, Tasha. 2018. Pengaruh Beauty Influencer Review Pada Youtube Terhadap keputusan pembelian Konsumen Wardah. Skripsi Program Studi Strata 1 Manajemen. Universitas Bakrie.

Rafita, Helsy Zella. 2017. Pengaruh Label Halal Terhadap Keputusan Pembelian Produk Kosmetik. Skripsi Program Ekonomi Syariah. UIN Raden Intan Lampung.

Ratnasari, R. T., Gunawan, S., Rusmita, S. A., \& Prasetyo, A. (2019). Halal Food Certification to Improve the Competitiveness of East and Middle Business in Indonesia. KnE Social Sciences, 1044-1056.

Rahman, Arif. 2019. Make Your Story Metter. Gramedia Pustaka Utama: Jakarta

Rosida, R. (2018). FAKTOR-FAKTOR YANG MEMPENGARUHI INTENSI PEMBELIAN KOSMETIK HALAL.Jurnal Ekonomi dan Bisnis Islam (Journal of Islamic Economics and Business), 4(2), 129-140.

Sandi, Aris Setyawan Prima, dkk. 2011. Persepsi Label Halal terhadap Keputusan Pembelian Konsumen pada Produk Minuman Berenergi. Jurnal Manajemen Bisnis Vol.1 No.2, Edisi Oktober

Saragih, Charles Victor B. 2013. Pengaruh Kualitas Produk, Ketersediaan Produk dan Gaya Hidup terhadap Keputusan Pembelian Produk Lulur Mandi Sumber Ayu Di Jakarta. Jurnal MIX. Vol. III, No.2: 211-230

Sinaga, Rumandong Eliza Maria dan Andriani Kusumawati. 2018. Pengaruh Beauty Vlogger terhadap Minat Beli Konsumen dan Dampak terhadap Keputusan Pembelian Produk (Studi pada Pengguna Kosmetik Maybelline di Indonesia). Jurnal Administrasi Bisnis. Vol. 63, No. 1:187-196

Simamora, Bilson. 2001. Remarketing for Business Recovery. Cetakan Pertama. Jakarta: PT. Gramedia Pustaka Utama.

Silsilia.O. Umboh,. A. Tumbel., D.Soepeno. 2015. Analisis Kualitas Produk, Brand Image Dan Life Style Terhadap Keputusan Pembelian Pakaian Wanita Di Mississippi Manado Town Square. Jurnal EMBA. Vol.3, No.1:1096-1105

Susanto, AB dan Himawan Widjanarko. 2004. Power Branding. Jakarta: Quantum Bisnis dan Manajemen.

Tarigan, Dewi Eka Setia. 2016. Pengaruh Gaya Hidup, Label Halal Dan Harga terhadap Keputusan Pembelian Kosmetik Wardah pada Mahasiswa Program Studi Manajemen Fakultas Ekonomi Universitas Medan Area Medan. Jurnal Konsep Bisnis dan Manajemen. Vol. 3, No. 1: 47 - 61 
Zukhrufani dan Zakiy |Jurnal Ekonomi dan Bisnis Islam, Vol. 5, No. 2, Juli - Desember 2019

Tri, Novi Haryanti dan Alexander Wirapraja. 2018. Pengaruh Influencer Marketing sebagai Strategi Pemasaran Digital Era Modern (Sebuah Studi Literatur). Jurnal EKSEKUTIF. Vol. 15, No. 1: 133-146

Yuniarti, Vinna Sri. 2015. Perilaku Kosumen Teori dan Praktik. Pustaka Setia: Bandung 